\title{
The decline of ethnographic film on British television
}

\author{
The 'LeSS-THAN-HAPPy MARRIAge': THE ACADEMiC \\ RECEPTION OF TELEVISION ETHNOGRAPHY
}

For a period of some twenty-five years, from the late I96os until the mid-I990s, the television patronage of ethnographic film-making served to give academic anthropology a public profile in Britain that it had not previously enjoyed and, arguably, has not enjoyed since. Although little more than anecdotal, there is some evidence to support the view that during this period the presentation of the work of anthropologists on television served to encourage students to apply to study anthropology at university, a valuable effect in a country where anthropology is almost entirely absent from the secondary school syllabus. ${ }^{1}$ Yet notwithstanding these positive circumstances, the reception of the films by British academic anthropologists during this period was, on the whole, no more than lukewarm.

Throughout the 'golden era', the ethnographic films broadcast on television were regularly reviewed by academic anthropologists in $R A I N$, the newsletter of the Royal Anthropological Institute (RAI), and in its successor publication, Anthropology Today, both under the film-sympathetic editorship of the then director of the Institute, Jonathan Benthall. (Significantly, films were only rarely reviewed in the more seriously academic journal of the Institute, which over this period still carried the anachronistic name of Man). Typically, these reviews would acknowledge the technical quality of the films and their potential use in teaching, but then go on to lament their deficiencies, be it in terms of content (because some aspect of the society portrayed in the film, that the reviewer deemed of fundamental importance, had not been dealt with in sufficient detail) or in terms of analytical framework (either because there was insufficient allusion to broader historical or political contexts, or because there was no explicit theoretical focus).

In later years, when reflexivity became a fashionable methodological posture in text-based anthropology, ethnographic films on television would be criticised on the grounds that they were insufficiently transparent about 
the circumstances of their own production and did not confess to the constructed and provisional nature of all representations of Otherness. But many of these reviews would then end with an acknowledgement - drawing to some extent their critical sting - that the film in question had, after all, been made for a mass television audience and therefore certain compromises would inevitably have been necessary in its making. ${ }^{2}$

However, while it is undeniable that the production of ethnographic films for television did require some degree of adjustment to the requirements of addressing a mass audience, underlying this tepid reception there was a more fundamental issue at stake, namely, the place of film of any kind, be it made for television or otherwise, in what Margaret Mead had famously described as a 'discipline of words'. For many academic anthropologists certainly then, if less so now - would probably have had some sympathy for the views expressed by my late Manchester colleague, Paul Baxter, in the course of a lengthy review in RAIN of The Rendille, a film about camel-herding pastoralists of northern Kenya that was directed by Chris Curling for the Disappearing World strand and broadcast in I977. Here, early in the review, in a much-cited passage, Paul admits to the sense that there is 'a basic incompatibility between the purposes of anthropology and the aims of film', since 'each seeks quite different aspects of truth and utilises quite different means of stitching scraps of culture together creatively'. In his view, whereas anthropology requires detailed probing of connections in order to arrive at always tentative conclusions, film in its 'bossy one-eyedness' necessarily involves an often seductively beautiful over-simplification. ${ }^{3}$

When he wrote this, Paul knew whereof he spoke in the sense that he had had relatively recent direct personal experience of film-making through working with James Blue and David MacDougall on a film about the Boran, another pastoralist group in the same region of Kenya. ${ }^{4}$ But while one might agree with him that films and texts do indeed differ in the way they creatively 'stitch together' accounts of social and cultural realities, this does not necessarily imply that they are 'incompatible', at least not within a more broadly conceived multimedia anthropology. On the contrary, I would argue that the intrinsic differences between films and texts as communication media offer the opportunity for complementary forms of ethnographic representation.

Indeed, the latter part of Paul's review, much less frequently - if ever - cited, suggests precisely this for, in seeming direct contradiction to his earlier strictures on the role of film in anthropology, he then proceeds to praise in generous terms what he sees as the sustained 'aesthetic and intellectual continuity' of The Rendille, in particular its 'constant, but unobtrusive, awareness of the physically close relationships and symbiotic interdependence of people and stock'. He comments with approval on the way in which the various different sequences dealing with political leadership, religious 
belief and the management of animals reinforce one another in an incremental fashion to demonstrate the fundamental rationality of the Rendille way of dealing with the highly uncertain ecological conditions in which they live. Although he notes some minor inaccuracies in the final part of the review, he concludes by expressing the hope that 'this film will persuade some influential people that the pastoral life is useful, productive and dignified so that they will seek to alleviate its hardships, not simply stop it'.

Paul Baxter was far from alone among British academics in holding reservations about ethnographic films made for television. The sceptics included even those who were generally well disposed towards film as a medium of ethnographic representation. In a series of articles published around the turn of the I990s, the leading British visual anthropologist, Marcus Banks, who had himself trained as a film-maker at the NFTS, questioned the whole project of making ethnographic films for television, suggesting that the involvement of anthropologists in television film-making had 'often' amounted to 'a less-than-happy marriage'. He pointed out that the decisions as to which films came to be made for television were usually taken by media professionals rather than by anthropologists with the result that the films did not necessarily reflect the priorities of the academic discipline: thus his own region of specialisation, India, although of great prominence in English-language academic anthropology, had been largely neglected by television ethnographic film series. Moreover, he argued, television ethnographic films tended to be conservative, not only stylistically but also in terms of their content, over-emphasising the study of the exotic as the defining feature of anthropology and, more generally, projecting an outdated image of the discipline as a whole. Given these circumstances, Banks proposed that anthropologists 'should not be afraid to say a polite "no, thank you"', at least to 'certain productions' and 'to welcome instead those that might be scorned by the media professionals'. 5

Even David Turton, who as the overall anthropological adviser to Disappearing World remained deeply committed to making ethnographic films for television, acknowledged that by the early I990s, the 'house style' of the strand had become outmoded and required 'radical revision'. He had various suggestions as to the forms that this revision should take, but the most fundamental was that the strand should abandon the 'distanced empiricism' that had characterised both academic anthropology and the strand when it first began in the I970s, and adopt instead a more reflexive mode of enquiry, so that the films would be presented to the television audience 'more as encounters than as observations, more as dialogue with than as dialogues about people'. This would mean that both anthropologists and film-makers would have to reveal more about themselves, including their mistakes and misunderstandings, which could be 'uncomfortable'. But, he believed, it would also make the films more interesting for the television 
audience and hence one could have the best of both worlds: not only would it make for better anthropology, it would also make for better television. ${ }^{6}$

\section{The Retreating TIDE OF ETHNOgRaphiC FILM ON TELEVISION}

But even as Banks and Turton were offering these criticisms and suggestions for rebooting the marriage of academic anthropology and television, the first signs of a separation were already apparent, and these would eventually lead to a full-scale divorce. Over the course of the I990s, the presence of ethnographic film on British television would be like an ebbtide: although there were temporary resurgences, the overall pattern was one of decline and retreat.

The initiative for this parting of ways came as much from the television as from the academic side of the relationship. For, by the beginning of the decade, the same neoliberal forces that Molly Dineen had shown at work in The Ark, described in Chapter I2, were also affecting British television. As a consequence of the Broadcasting Act of I99I, the obligation on franchise holders to produce educational material diminished and the importance attributed to audience viewing figures correspondingly increased. At the same time, with the emergence of television delivered through extra-terrestrial satellites, the number of channels available in Britain increased exponentially. Until I982, when Channel 4 came on stream, there had only been three channels: two were public service broadcasting channels operated by the $\mathrm{BBC}$, the other was a commercial channel operated on a regional franchise basis. It was on this commercial channel that the Disappearing World films were broadcast. But by the end of the I980s, there were at least forty channels, mostly operating on the basis of exclusively commercial criteria and no longer necessarily tied to regional franchises. ${ }^{7}$

This combination of factors directly conspired against the making of ethnographic films for television. For relative to the numbers of viewers who wanted to watch them, ethnographic films were expensive to make as they typically involved long shoots, usually abroad. In an unmitigated cost-benefit equation of production costs balanced against audience figures, a game show had always been a more commercially attractive proposition than an ethnographic film: only the obligation to produce educational programming had weighted the balance towards ethnographic film. Moreover, in a three- or four-channel environment, if an ethnographic film was showing on one channel, potential viewers did not have many other choices, so they might stay with the ethnographic programme, even if their first preference might not have been to watch a subtitled film about, say, symbiotic relationships between pastoralists and sedentary agriculturalists in East Africa. These 
circumstances explained why, in I982, a Disappearing World film on just such a topic, The Kwegu, could earn viewing figures of several million people when it was broadcast, at prime time, on a weekday evening. But by the early I990s, the ground rules were very different and viewing figures for ethnographic films began to fall drastically. As a result, in the particular case of Disappearing World, the programmes were scheduled at increasingly later times, outside prime time. Predictably, in the implacable Catch-22 logic of television, this merely increased the decline in viewing figures so that eventually, in I993, the series was finally and definitively axed.

Similar processes were taking place during this period across British television, on the $\mathrm{BBC}$ as well as on the commercial channels. The general pattern of temporary resurgences within an overall pattern of decline is well exemplified by the BBC strand Under the Sun, which produced around 50 programmes between 1989 and 1999 over the course of ten series. The first executive producer was Chris Curling, who moved to the BBC studios at Elstree on the northwestern outskirts of London, after the Worlds Apart strand produced out of the BBC Bristol studios had come to an end. However, the format of Under the Sun was significantly different from that of Worlds Apart. Although all ten of the programmes in the first series, which straddled I989 and I990, were in some sense about 'other cultures' and, as such, of potential ethnographic interest, only one was directly based on the field research of an academic consultant anthropologist. This was The Shaman and His Apprentice, based on the work of Graham Townsley among the Yaminahua of Peruvian Amazonia and directed by Howard Reid, who held an anthropology doctorate from Cambridge and had first entered television as a researcher on the Worlds Apart strand. ${ }^{8}$

The same overall pattern was repeated in later series of the Under the Sun strand, as series producers with no connection to anthropology succeeded Curling. Even so, there continued to be occasional examples of films that were based directly on the ethnographic research of academic anthropologists, and which were of a quality that rivalled the best that Disappearing World had been able to achieve in its heyday. One example was an impressive trilogy of films about the Hamar pastoralists of southern Ethiopia produced over the course of several series of Under the Sun between I990 and I994. These films were directed by Joanna Head, a School of Oriental and African Studies (SOAS) anthropology graduate who had also entered television as a researcher through Worlds Apart, and were made in collaboration with Jean Lydall, the anthropologist who, with her husband, Ivo Strecker, had worked on Robert Gardner's Rivers of Sand. ${ }^{9}$ Meanwhile, another SOAS anthropology alumnus, Jean-Paul Davidson, directed two films about the Mehinacu of the Xingu National Park in Central Brazil based on the work of eminent Amazonist Thomas Gregor, who had been one of the consultants on the celebrated I974 series of Disappearing World. One of these, 
Feathered Arrows, was broadcast in I990, and the other, Dreams from the Forest, in I993. $^{10}$

Yet another SOAS alumnus, MichaelYorke, who had completed a doctorate based on his work with the 'tribal' Gond population and acted as both director and academic consultant on the Worlds Apart strand, also made a number of films for Under the Sun. These included the remarkable Dust and Ashes, which featured in the 1989 series, and which concerned the vast Kumbh Mela pilgrimage to the banks of the Ganges near Allahabad. The following year, the strand featured The Left-handed Man of Madagascar, a film based on the work of anthropologist John Mack, then of the British Museum, and directed by Jeremy Marre. In the I994 series, Paul Reddish directed Guardians of the Flutes, a film about male initiation, in collaboration with the eminent Melanesianist anthropologist Gilbert Herdt. But these examples were few and far between: the great majority of films made for the Under the Sun strand as it continued through the I99os had little or no connection to academic anthropology.

Films based on the work of academic anthropologists and conforming broadly to the one-by-four format still continued to surface occasionally on Channel 4. In I99I, this channel broadcast a four-part series, Nomads, three of which were based on the work of academic anthropologists. From time to time, the ecology-oriented strand, Fragile Earth would also include a film of this kind. In I993, it broadcast Survivors of the Rainforest, a film about the Yanomami of Venezuelan Amazonia. This was directed and shot by Andy Jillings, a film-maker trained in the Observational Cinema approach at the NFTS, while the anthropologist-consultant was the French anthropologist, Jacques Lizot, who by that time had been working with the Yanomami for some twenty-five years, more or less consecutively. Though not well known in academic circles, this film represented a considerable advance on the films in the Asch-Chagnon canon: not only is it much better shot, but it is editorially richer in an ethnographic sense too. The central feature of this film, as in the Asch-Chagnon work, The Feast, is a collective feast aimed at re-establishing the alliance between two warring villages. But in this case, not only is the feast itself presented, but the background to the tension between the two villages is explored as well (figure I3.I). This film also covers a number of other topics, some of which are also covered in the Asch-Chagnon films (shamanic curing, children playing) but some of which are not, notably an extended sequence on funerary practices. ${ }^{11}$

Another example of a temporary resurgence within the general ebbing away of ethnographic film on British television in the I99os was the Fine Cut strand, for which André Singer acted as the first series producer. Singer's brief on his appointment was to schedule 'auteur' feature documentaries and under this guise, 'almost by subterfuge' as he himself has put it, Fine Cut supported either the making, or the broadcasting, of a number of films 


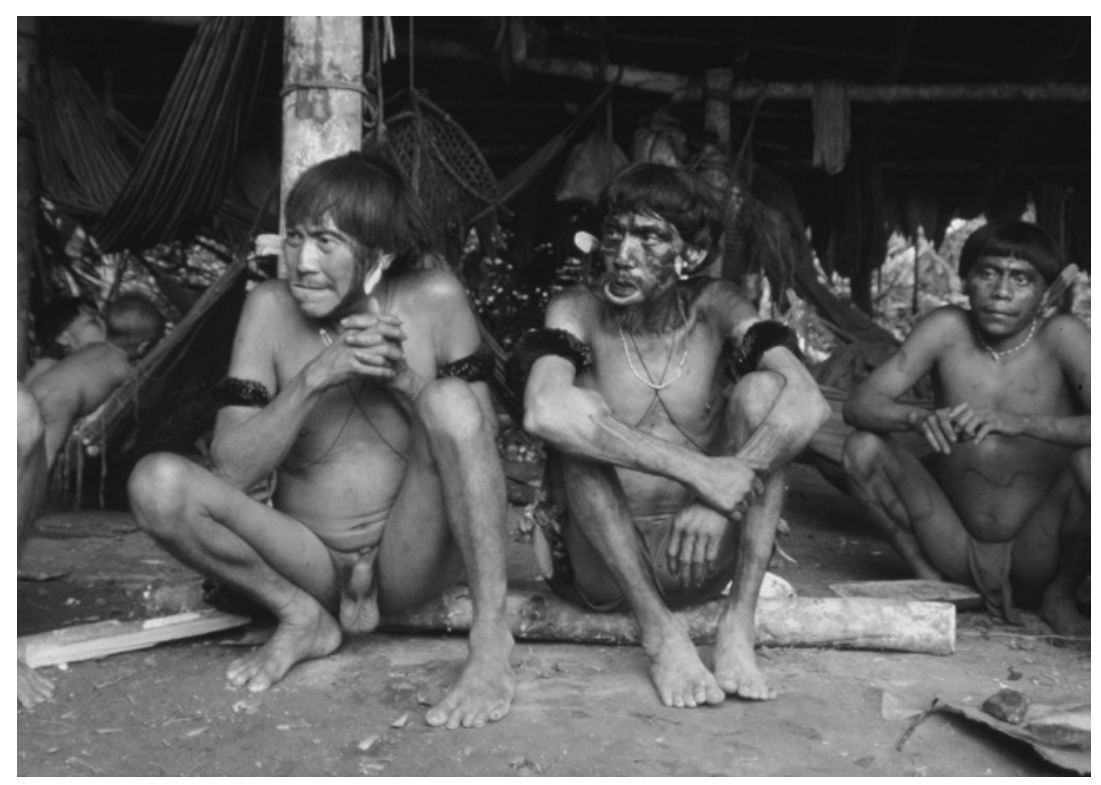

I3.I Survivors of the Rainforest (1993). During a three-day feast of reconciliation between warring villages, Hisiwe, left, leader of a Yanomami village on the upper Orinoco, Venezuela, sits with his guests as they watch the dancing.

by leading ethnographic film-makers. These included Robert Gardner's masterwork, Forest of Bliss and Jean Rouch's late work, Madame l'eau. The strand also broadcast Titicut Follies, a portrait of a Massachusetts institution for the 'criminally insane' that was directed by Fred Wiseman and shot (in some accounts co-directed) by John Marshall, which in the USA had languished under a ban for many years. It also produced Melissa LlewelynDavies's Memories and Dreams (discussed at length in Chapter I2), and contributed to the budget of David MacDougall's film, Tempus de Baristas, released in I993 (to be considered in Chapter I4). But Singer then left the strand and in 1994, it was put in the charge of Nick Fraser, who changed the strand name to Storyville, which it retains to this day. Fraser's interests in documentary lay elsewhere and once he took over, the strand no longer supported ethnographic film-making. ${ }^{12}$

\section{THE PERSISTENCE OF PARA-ETHNOGRAPHIC FILM-MAKING}

Although films based explicitly on academic ethnographic research were becoming increasingly rare as the I990s progressed, British television continued to support documentary series that were 'para-ethnographic' in the sense 
defined in the Introduction to this part of the book. Paul Watson returned to the form in two series that were very different in terms of their subject matter but which were both based on participant-observation of the subjects over a prolonged period: one of these, Sylvania Waters, concerned a nouveau riche middle-class family in a wealthy suburb of Sydney, broadcast by the BBC in I992, while the other, The Factory, produced for Granada Television in I995, followed the struggles of one of the last remnants of manufacturing in what had once been a highly industrialised part of Liverpool. Both series, in their different ways, confirmed Watson as an acute and critical observer of the cultural attitudes and practices that serve both to demarcate and sustain class differences. This was a seam that had run through all his work since The Family, including also his oblique but highly controversial 'flyon-the-wall' representations of British elites in one-off documentaries such as The Fishing Party (1986) and later, The Dinner Party (1997).

Other notable examples of para-ethnographic works on British television in the I990s include two remarkable series that Phil Agland shot in China. The first, Beyond the Clouds, in seven parts and broadcast in I994, was filmed in and around the traditional town of Lijiang in Yunnan province, in the southwest of the People's Republic, while the second, Shanghai Vice, also in seven parts and broadcast in I999, concerned China's so-called 'second city'. Both series were built on the same mix of authorial strategies that Agland had deployed in making Baka: two years in production permitting the development of relationships of trust with the protagonists as well as an understanding of their situation and the necessary linguistic competence; an interwoven set of narratives constructed around the experiences of a small group of key characters; observational cinematography of the absolutely highest quality which was then cut according to the continuity codes of fictional cinema, with assistance from an actorly voice-over and passages of extra-diegetic music with a local flavour. There were no interviews: instead the voice-over served as the principal means for providing the necessary social and political contexts. ${ }^{13}$

Whereas Baka had been based around a single local group and had focused mostly on one particular nuclear family, the cast of characters of Agland's Chinese films was much broader and they were related to one another primarily by geography rather than through family ties. In Beyond the Clouds, these characters come from various different groups within Lijiang and include an acupuncturist doctor, a butcher, a schoolteacher and a carpenter from the localYi ethnic minority, as well as four elderly 'grannies' who dress in traditional Naxi minority dress and do everything together. In Shanghai Vice, they include the daughter of the Lijiang doctor, Teng Shao, who has come to Shanghai to study, thereby linking the two series, as well as a diverse range of other characters, including Teng Shao's landlady, the latter's gentleman companion who is a professor of Japanese, a well-known 

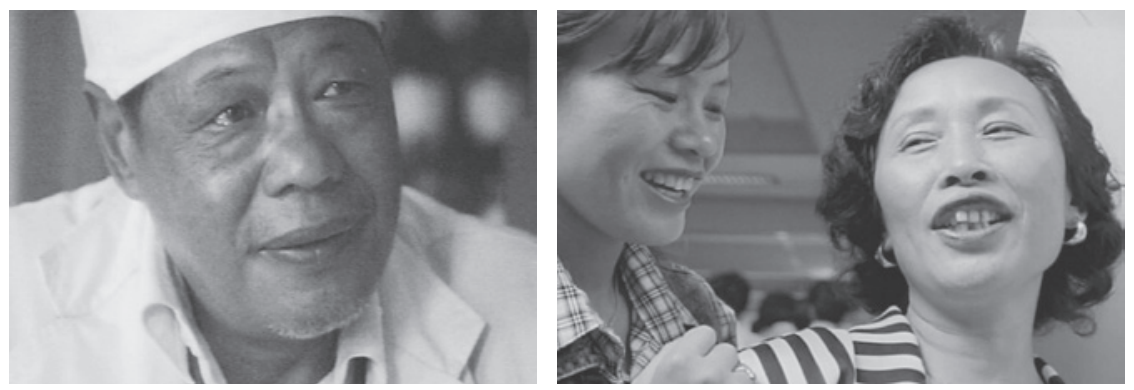

I3.2 Film series made in China by Phil Agland. Left, the acupuncturist

Dr Teng is a leading character in Beyond the Clouds (I994), while his daughter, Teng Shao, and her extrovert landlady, Mrs Feng, right, feature prominently in Shanghai Vice (1999).

radio talk-show host, a group of Chinese opera performers, as well as a young boy suffering from a serious heart condition and the surgeon who operates on him (figure I3.2).

While the Chinese films continue to focus on intimate personal experience, and even include sequences in which characters discuss their love life in a relatively uninhibited manner, the underlying themes are social and political rather than ecological, as they had been in Baka. One of these themes, which emerges in Beyond the Clouds and then becomes central to Shanghai Vice, is crime and its (sometimes capital) punishment in contemporary Chinese society. Indeed, the title of the latter series is a reference to the fact that one of the most important characters is Zhu Daren, a leading figure in the Shanghai police force: the work of Zhu and his colleagues in tackling murderers, rapists and particularly drug-dealers serves as one of the principal vehicles through which we are introduced to everyday life in contemporary Shanghai. The access that Agland gained to the most undercover of these police activities was truly extraordinary, particularly in a totalitarian state not known for its concern for transparency. The action cuts back and forth between the lives of the various characters, and through this mosaic offers the audience what is, in effect, a thoroughly engaging ethnographic portrait of the city as it opened up following the reforms promoted by Deng Xiaoping.

Another film-maker working in a para-ethnographic manner and whose work became prominent on British television over the I990s was Kim Longinotto. Like Toni de Bromhead and Molly Dineen, Longinotto had also trained as a film-maker at the NFTS in the heyday of the observational ethos there and like them, she shoots all her own material, always supported, in her case, by a woman sound recordist. However, Longinotto had attended the school somewhat earlier than de Bromhead and Dineen, that is, in the 

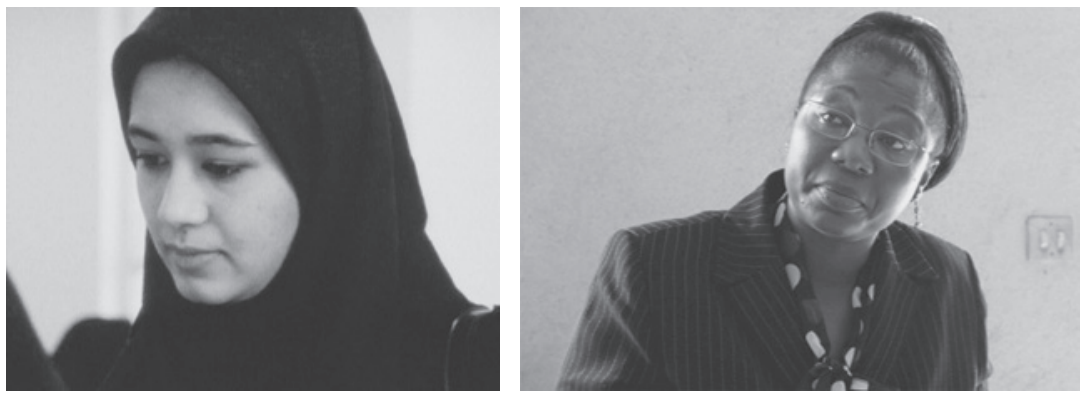

I3.3 Films by Kim Longinotto. Left, in Divorce Iranian Style (2004), a woman pleads for divorce in an Islamic court in Tehran; right, on the other side of the bench, a Senegalese judge dispenses justice in Sisters in Law (2005).

mid-I970s when the dominant influence in the documentary department was more the approach of Direct Cinema than the anthropologically inflected Observational Cinema approach that would become prominent in the school in the I980s. Perhaps for this reason, Longinotto's authorial signature is less overtly reflexive and certainly less conversational than the authorial signatures of de Bromhead and Dineen.

Throughout a long career, embracing more than twenty films, the recurrent leitmotif of Longinotto's work has been women's struggle to throw off repressive or restrictive gender roles, a theme that she has pursued in a number of different cultural contexts around the world. In the early I990s, she made a number of films about women contesting conventional gender roles in Japan, two of which were broadcast as part of the BBC's Under the Sun strand. But in I998, she expanded her range, collaborating with the Cambridge-trained Iranian legal anthropologist Ziba Mir-Hosseini to make Divorce Iranian Style, a feature-length film produced for Channel 4 that followed the struggles of three women to secure their rights in an Iranian divorce court (figure I3.3, left). In order to make this film, which was shot over a period of a month, the all-women crew and Mir-Hosseini meticulously observed Islamic dress codes whenever they were filming in the court. ${ }^{14}$ Three years later, Longinotto and Mir-Hosseini returned to Iran to make Runaway, also for Channel 4, which offered a classical observational portrait of an institution, in this case, a refuge for girls who have run away from repressive family environments.

Since these Iranian films, Longinotto has made an impressive series of feature-length television documentaries about women who reject conventional expectations or who campaign against injustice in many different parts of the world. These films, sometimes made in collaboration with a co-director, have featured such diverse subjects as the team of doughty female wrestlers 
in Japan who are the focus of Gaea Girls (2000), the equally redoutable Cameroonian lawyers who are central to Sisters in Law (2005) and the extraordinary Tamil women's rights poet and activist who is the eponymous principal character of Salma (20I3) (figure I3.3, right). Although none of these later films involved collaboration with academic anthropologists, their ethnographic qualities have been recognised in their frequent selection for self-definingly ethnographic film festivals, where they have been awarded prizes and commendations. Another indirect indicator of their ethnographic status is that almost all Longinotto's major films are now distributed by the Royal Anthropological Institute. ${ }^{15}$

Towards the end of the I990s, a rather different form of para-ethnographic film-making became prominent on British television. This was enabled by developments in lightweight digital video technology which allowed a single person to shoot and at the same time to record sound with the aid of radio microphones, while also maintaining a sufficiently high technical standard for the work to be broadcast on national television. One of the pioneers of this way of working was Chris Terrill, who holds a doctorate from the University of Durham based on anthropological fieldwork in southern Sudan. In interviews, Terrill has explained that participant-observation over an extended period, the attempt to see the world through the subjects' eyes and a non-judgemental ethical positioning - all classical markers of the ethnographic method - are central to his practice as a film-maker. Having already worked with a conventional crew to make HMS Brilliant, an observational series broadcast by the BBC in I995 about life on board a naval ship, Terrill shot and recorded the twelve-part series Soho Stories on his own. First broadcast on BBC Two in I996, this offered a portrait of the well-known red-light and entertainment zone in central London through interweaving the personal stories of a varied collection of its inhabitants. Later, he applied the same methods to a range of institutions, including a cruise ship, a women's prison and various military and naval units on active service.

These developments in lightweight digital technology also underpinned the emergence of a new system for producing documentary series for British television around this time. This involved the commissioning, within the general rubric of a given series, of a number of freelance film-makers to make films for which they would act as camera operator, sound recordist and 'on-location director'. However, the editing of the footage that they produced would then be entirely controlled by the series producer and if the 'on-location directors' entered the edit suite at all, it would be merely to offer suggestions on the cuts produced by the series producer and the editor.

The production company Mosaic Pictures played a leading role in developing this format and produced a number of series in this way, including 

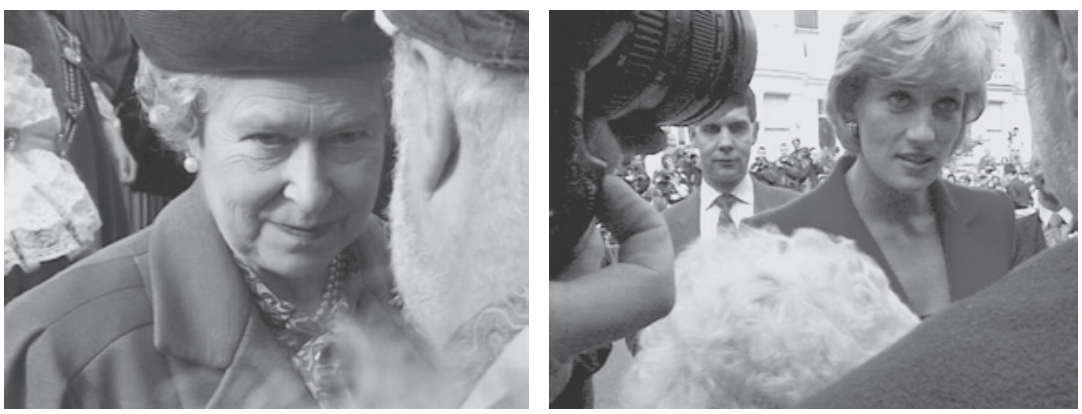

I3.4 Royal Watchers (I997). The Queen, left, meets the 'royalists' outside Lincoln Cathedral in October 1996, while Diana, Princess of Wales, right, meets the same group in London three days later.

series about Russia, the UK and the European Union. Although some of the films produced for these series had certain para-ethnographic qualities, very few were based on anything that one could describe as extended ethnographic research. One exception was Royal Watchers, produced by Mosaic Pictures in I997. I myself shot, took sound and directed this film on location, and it was made in active collaboration with the Manchester anthropologist Anne Rowbottom. Broadcast by BBC Two as part of their series United Kingdom, this film was based on Rowbottom's doctoral research into popular perceptions of the British monarchy and, in particular, her fieldwork among a highly dedicated group of self-defining 'royalists' who travel all over the country to attend royal 'walkabouts' (figure I3.4). ${ }^{16}$

Over the same period, lightweight digital technology was also associated with the development of the so-called 'docu-soap' format on British television. In contrast to the para-ethnographic works of Watson or Dineen, Agland or Longinotto, or even the series produced by Mosaic Pictures, it was no longer a central concern for those working in the docu-soap format to make some sort of comment upon social or political matters. Rather, the principal aim was simply to follow the interplay of a select group of personalities, often carefully chosen on account of their eccentricity, with the action cutting repeatedly back and forth between them in a series of very short scenes, in the manner of a fictional soap opera.

While arguably even these series could be said to have had certain minimally descriptive ethnographic qualities, the subject matter was typically very trivial, focusing on the most banal activities of the practitioners of particular occupations, such as driving instructors, traffic wardens, vets and holiday tour 'reps'. Soon, even these modest real-life ethnographic contexts were abandoned as the format morphed again and was reduced merely to the interplay of eccentric personalities in the entirely artificial social environment of the Big Brother house. ${ }^{17}$ 


\section{ETHNOGRAPHIC FILM-MAKING ON BRITISH TELEVISION SINCE}

By the early years of the new century, film-making based directly on ethnographic research by academic anthropologists in particular communities or with particular groups of people had almost disappeared without trace from British television. In the latter part of the I990s, a number of series involving co-production deals with US television channels had dealt with such classical anthropological topics as magic, sacrifice, head-hunting and cannibalism, but these were more in the comparative format of earlier BBC series such as Family of Man and Face Values as described in Chapter II. That is, the constituent programmes were typically structured around a central argument delivered through voice-over commentary that was then illustrated by footage relating to a range of different societies. This footage was often second-hand or archival rather than being dedicated material shot expressly for the series in question. Over time, these co-productions had a tendency to become increasingly archaeological or historical rather than anthropological, dealing with such topics as mummification, Ancient Egypt or medieval witchcraft. ${ }^{18}$

In 200I, commissioned by the Channel 4 strand, True Stories, Leslie Woodhead and David Turton returned to Ethiopia to make a sixth film with the Mursi. This was Fire Will Eat Us, which showed how the Mursi had been reduced to performing a simulacrum of their life for tourists. But this was possibly the very last example of a British television film based directly on academic research according to the classic 'one-by-four' model developed on Disappearing World. By 2003, a leading British anthropologist could lament in print, only partly in jest, that the only time that anthropology was likely to be referred to on British television was in the form of a particularly difficult quiz show jackpot question, 'What is anthropology?' ${ }^{19}$

The situation has not changed significantly in the years since then: the tide of anthropologically informed ethnographic film on British television remains at a very low ebb. In 2004, a new strand appeared on British television screens, produced by BBC Wales, which was widely dubbed as 'anthropological' in the British press, including in the more 'serious' newspapers. This was Tribe (screened on US television as Going Tribal), a travel show featuring a supposedly intrepid explorer, a former Royal Marine and physical education instructor, who visited 'tribal' peoples around the world for up to a month at a time, submitting himself to physical ordeals in the process. In each programme, he gave simple to-camera explanations about the way of life of his hosts and usually made something of a fool of himself trying to perform traditional male tasks, much to his hosts' amusement. At the end of each programme, he would routinely declare how honoured he felt to 
have been received by his hosts and that he would never forget the experience of getting to know them.

This presenter had no anthropological training, did not speak the local languages and his visits were very short, at least by anthropological standards, so not surprisingly his understanding of the societies whose lives he presented to the world was no more than superficial. To do them justice, although the series clearly played into popular perceptions of anthropology, the producers themselves never claimed that the strand was anthropological. The academic anthropologists who reviewed Tribe radically disowned it, but in terms of audience viewing figures it was highly successful, and went through three series. ${ }^{20}$

More generally, if anthropologically informed ethnographic film-making has been taking place at all on British television since the millenium, it is because anthropology graduates continue to enter British television taking with them certain anthropological ideas, attitudes and methods that can remain discernible in their work, even if they are heavily overlaid by the stylistic conventions and formats of present-day British television production. A good example here is Welcome to Lagos, a three-part series produced by Keo Films for the BBC, which was broadcast in 2010 and won several highly prestigious awards, including from the Royal Television Society and BAFTA, the British Association of Film and Television Arts - the British equivalent of the Academy of Motion Picture Arts. The series was shot in an observational manner over a period of several months by Gavin Searle, and executive produced by Andrew Palmer, both of whom had studied with us at the Granada Centre for Visual Anthropology at the University of Manchester.

This series follows the experiences of a number of different subjects living in the most marginal areas of the most populous urban centre in Africa. Many of those featured in the series had migrated to the Nigerian mega-city from all over West Africa in search of a better life, and rather than bemoaning their poverty and deprivation, Welcome to Lagos celebrates their resourcefulness and enterprise (figure I3.5). In both these respects, the series is reminiscent of, and a worthy successor to, Jaguar, Jean Rouch's classic film about migrants to Accra and Kumasi shot in the mid-I950s, even if some viewers had reservations about the patronising tone of the voice-over commentary and the Nigerian government detested it because it suggested that the whole of Lagos consisted of shanty towns.

But apart from these almost covert examples of programmes underpinned by an ethnographic sensibility, there is little evidence of a turning of the tide and a return to anything like the vast investment of time and resources in films based directly on academic anthropologists' research that was a defining feature of the 'golden era' of ethnographic film on British television. This is a matter of regret, of course, but this regret about the present state 

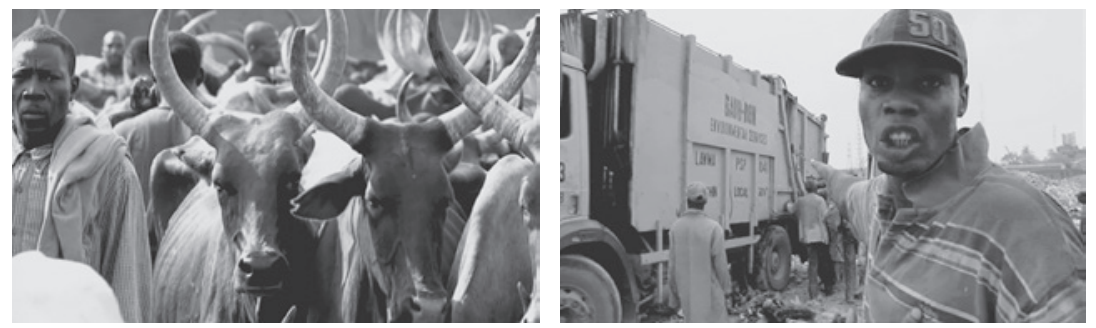

I3.5 Welcome to Lagos (20I0). Left, cattle are brought to Lagos market from as far away as Chad and Southern Sudan. Right, Eric Obuh, aka

'Vocal Slender', scavenges in the rubbish tip to pay for his music recording career.

of affairs should not blind us to the value of the legacies left by that immensely productive period.

\section{The Legacies of British TeleVision ETHNOgRaphy}

As I described at the beginning of Chapter II, the great commitment to ethnographic film-making on British television during the 'golden era' can be traced to the unique circumstances of commercial television in the post-war period and, more particularly, to Sir Denis Forman's highly personal belief that a series of ethnographic films about groups whose very existence was under threat would result in an archival record that would be of inestimable value in the future. Even in the early I970s when the Disappearing World strand first began, this interest in 'salvage' ethnography was regarded by many anthropologists as highly anachronistic. By the time the strand ceased in I993, it had become even more out of tune with what were then the cutting-edge concerns of the academic discipline of anthropology as a whole.

Yet even while one might readily acknowledge these intellectual limitations and while it seems that all the groups who featured in the series, even the Cuiva, have survived physically, there can surely be no doubt that in the four decades since Disappearing World was first broadcast, the great majority of these groups have undergone major social and cultural changes as they have become progressively incorporated into a more globalised world. Thus, however contestable the original motivations or however inappropriate the series title, the ethnographic films produced for British television, either by the Disappearing World strand itself or by its many imitators, offer a now irreplaceable account of the social and cultural diversity of the world as it was in the second half of the twentieth century. 
Moreover, although they may have been given only a lukewarm reception by academic anthropologists at the time they were made, the films of the Disappearing World strand continue to be widely used in the teaching of anthropology both in Britain and the USA, despite the fact that even the most recent of these films is more than twenty-five years years old. ${ }^{21}$ In part, this is because although, in theory, given the greater technical ease and lower cost of making films with digital technology, academic anthropologists could now be making their own ethnographic films, as has often been optimistically proposed by critics of television films in the past, in practice this has simply not happened, certainly not to any major extent. The reasons for this are too complex to consider here, but they include the continuing low status of ethnographic film-making in a 'discipline of words' and the associated difficulty of accruing any professional academic credit from making ethnographic films. This is compounded by the continuing failure on the part of many academic anthropologists to appreciate the potential of visual media for communicating their knowledge and understanding not just to non-specialist audiences, but also to their academic colleagues.

But the films themselves are not the only legacy of the sponsorship of ethnographic film-making by British television. Another of which I am particularly aware, for obvious reasons, is the Granada Centre for Visual Anthropology, which was created as a direct result of the Disappearing World strand. In the first instance, it was the product of a joint initiative by David Turton, overall anthropological consultant to the strand, and then a member of staff of the Department of Social Anthropology at the University of Manchester, and Leslie Woodhead, the Disappearing World producer-director with whom Turton had collaborated in making a trilogy of films about the Mursi pastoralists of Ethiopia between I974 and I985, as described in Chapter II. In I987, with the active support of Marilyn Strathern, head of the Department of Social Anthropology, Turton and Woodhead persuaded David Plowright - who with Denis Forman had been one of the original initiators of Disappearing World and who was by then the chief executive of Granada Television - to provide some financial backing for the creation of a centre that would offer a Masters programme in visual anthropology.

The sum provided was relatively modest, and was far outweighed by the investment made in the centre by the University of Manchester itself. But it was offered entirely without strings and continued on an annual basis until as late as 2007, long after the closure of Disappearing World in I993. As such, it acted as seed-corn funding that allowed us to develop the centre in a variety of different directions, including the creation of a doctoral programme to supplement the original Masters programme, and more recently, a short course aimed specifically at ethnographic researchers. As a result, several hundred people from all over the world have now been 
instructed in practical ethnographic film-making as they have passed through these various programmes. ${ }^{22}$

There is, finally, a somewhat more intangible but equally important legacy of the twenty-five years of sponsorship of ethnographic film-making by British television. During that time, many talented film-makers - including here cinematographers, sound recordists and editors as well as producerdirectors - became involved in making ethnographic films for television and developed a broad and highly skilled range of ways of doing so within the constraints of the need to address audiences counted in millions. As I have described in earlier chapters of this book, there is a long tradition in ethnographic film-making of drawing upon modes of authorship first developed outside the specialist, mostly academic world in which ethnographic film-making has typically been practised: just as Jean Rouch was inspired by Robert Flaherty, so Robert Gardner was inspired by Basil Wright and Colin Young by the Italian Neorealist cinema. In the same way, rather than looking down on them because they were produced for a mass medium, as is too frequently the tendency, ethnographic film-makers would do well to study the films produced for British television in the 'golden era' and explore the ways in which the authorial praxes that their makers developed for making films in that environment could enrich their own repertoires.

\section{Notes}

1 In 1989, the Royal Anthropological Institute carried out a survey among first-year students of anthropology, receiving 256 responses. Of these, 25 per cent said that they had first come across anthropology through 'seeing films or TV programmes', a proportion exceeded only by 'talking to friends or relatives' ( 27 per cent) and considerably higher than 'reading books' (I8 per cent) or 'advice from schoolteacher' (9 per cent). See Richardson (I990).

2 When the Disappearing World series was exported to the USA and shown on television there, reviews also began to appear in American Anthropologist. Although these could sometimes be highly dismissive, they tended on balance to be more appreciative than the reviews written by British academics. I suspect that this was a consequence of the fact that at that time, US anthropologists had been using film in teaching for much longer than their British colleagues and were more accustomed to assessing them on their own terms as films rather than as failed texts. It was probably for this same reason that the producers of the Disappearing World strand found that there was generally a much greater interest on the part of US academics in acting as consultants on the strand (David Wason, personal communication, September 20I4). See also the comments of Terence Turner, a US anthropologist who worked in the UK as a consultant for both the BBC and for the Disappearing World strand (Turner I992b).

3 Baxter (1977).

4 See p. I73 note 5 regarding Baxter's work with Blue and MacDougall on Kenya Boran.

5 See Banks (i988); (I992), iı6; (1994).

6 Turton (1992a).

7 See Singer (1992), 271; Singer with Seidenberg (1992), I24.

8 See Banks (1994), 25-30 for an overview of the first two series of the Under the Sun strand. 
9 See Chapter 9, pp. 260-I and also Chapter I6, pp. 470-6 for an extended discussion of these films as well as of Duka's Dilemma (2002), a fourth film about the Hamar directed by Lydall independently of the BBC.

10 Around the same time, Jean-Paul Davidson also directed a film about another Xinguano group, the Waurá, in collaboration with the Yale anthropologist, Emelienne Ireland, for a different BBC strand, Bookmark. This charming film, The Storyteller, broadcast in I990, concerns the enactment of mythological events by the Waura and anticipates the films made by the Video nas Aldeias film-makers Takumã and Maricá Kuikuro, as discussed in Chapter 7, pp. 216-I8.

11 For a more detailed review of this film, see Henley (I999). See Chapter 4, for a discussion of the Asch-Chagnon films, pp. I42-9.

12 It was Nick Fraser's rejection of David MacDougall's proposal to make a film about the Doon School in India that in I997 led MacDougall to begin shooting with very much cheaper digital technology and to adapt his authorial strategies accordingly. See Chapter I4.

13 See Chapter I2, pp. 352-5 for a discussion of Baka.

14 Ziba Mir-Hosseini has published an interesting account of the making of Divorce Iranian Style and the diverse reactions to the film afterwards, both within Iran and abroad (2002). A sign of the times is the striking contrast between the obligation on Mir-Hosseini, Longinotto and their colleagues to wear the full hijab in order to make their film in Iran in 1997 with the situation twenty years earlier when the all-women crew took off all their clothes to shoot one of the scenes in Some Women of Marrakesh, as described in Chapter II, p. 336.

15 See raifilm.org.uk/films/.

16 See Rowbottom (2002a, 2002b).

17 For a good discussion of docu-soaps, see Bruzzi (2000), 75-98.

18 A number of these thematic series made in collaboration with US channels were executively produced by André Singer. These included Divine Magic (1996), a ten-part series for Channel 4 and Discovery Channel, and Forbidden Rites (I999), a three-part series co-produced and co-directed with Tom Sheahan for the National Geographic Channel and also screened on Channel 4.

19 Sillitoe (2003), 2.

20 For critical assessments, see Caplan (2005) and Hughes-Freeland (2006). But see also the response of Andre Singer, who was involved in the production of the series (Singer 2006).

21 In the five year period 2009-I4 the RAI, one of the principal distributors of films from the Disappearing World strand, sold an average of around I5O copies of the films a year, mostly to educational institutions for teaching purposes (Susanne Hammacher, RAI Film Officer, personal communication, October 20I4).

22 Granada Television itself has not merely abandoned ethnographic film-making but all forms of factual film-making, including even its flagship current affairs programmes. In fact, in legal terms, it now exists only as a regional badge for the London-based media corporation, Independent Television (ITV). 
Paul Henley - 9781526147295 Downloaded from manchesterhive.com at $04 / 26 / 2023$ 12:37:36PM via free access 